\title{
(7)
}

\section{Balochistan: Overview of its Geo-economic and Socio-economic Perspectives}

\author{
Aziz Ahmed $^{\mathrm{a}}$, Noor Mohammad ${ }^{\mathrm{b}}$, Abdul Wadood ${ }^{\mathrm{c}}$ \\ ${ }^{a}$ Lecturer, Department of Economics, Faculty of Management Sciences, Balochistan University of Information \\ Technology, Engineering and Management Sciences, Quetta, Pakistan \\ Email: aziz.ahmed@buitms.edu.pk \\ ${ }^{\mathrm{b}}$ Associate Professor, Department of Management Sciences, Faculty of Management Sciences, Balochistan \\ University of Information Technology, Engineering and Management Sciences, Quetta, Pakistan \\ Email: noor.muhammad@buitms.edu.pk \\ ${ }^{c}$ Assistant Professor, Department of International Relations, Faculty of Arts and Basic Sciences, Balochistan \\ University of Information Technology, Engineering and Management Sciences, Quetta, Pakistan \\ Email: abdul.wadood@buitms.edu.pk
}

\begin{tabular}{l}
\hline ARTICLE DETAILS \\
\hline History: \\
Accepted 26 May 2020 \\
Available Online 30 June 2020
\end{tabular}

Keywords:

Geo-Economic; Socio-Economic;

Development; Balochistan

\section{JEL Classification:}

A12, A13, B40, O1O

DOI: $10.10 .47067 /$ ramss.v3i2,58

\begin{abstract}
This study gives an overview of geo-economic and socio-economic perspectives of Balochistan. The research methodology of descriptive analysis is used to highlight the objectives of this study on thematic analysis outcomes. The findings of the study show paradoxical themes that Balochistan is the largest and resourceful yet the least developed province of Pakistan. The major portion of population comprises of youth but not skilled enough to find decent works for livelihood earnings. Political awareness is present, but the government is made on the consent of governments formed at federal level. Economic snapshots reveal that resource-rich attributes of the province are associated with the lowest socio-economic indices across all districts of the province. The natural cum geo-economic importance and resources abundance have not contributed for socio-economic development of this backward province of Balochistan. Unemployment, low skills development, zero industrialization and socio-economic backwardness are main economic issues responsible for the lowest development of the province. The policy recommendations include the implementation of comprehensive development policies for natural resource development, human capital formation of its labor force, coastal area development, development of Gwadar sea-port, enhancing capacity building of the provincial government departments, rule of law, investment for socio-economic development and mainstreaming the local population in macro decision making for the development of the least developed province of Balochistan.
\end{abstract}

(C) 2020 The authors. Published by SPCRD Global Publishing. This is an open access article under the Creative Commons Attribution-

NonCommercial 4.0

Corresponding author's email address: abdul.wadood@buitms.edu.pk 


\section{Introduction}

Balochistan is the largest province, by area size, in Pakistan, yet the least developed too. It constitutes $43 \%$ of the whole area of Pakistan. This province contributes around $6 \%$ as its share to the national population, thus representing the most void region in the country of 120 million people. Population per square kilometer is the lowest in the country (GOP-PBS, 1998; Population Census, 2017).

Historically, Balochistan has been the part of Mehrgarh civilizations some 9000 years ago. It has also witnessed the Iranian, Macedonians, Arabs, Ghaznavides, Afghans, Mongols, and Mughals in the past. British also ruled over British Balochistan (Pashtun dominant regions) and subjugated Baloch states of Mekran, Qalat, and Bela until the creation of Pakistan and India. Balochistan has adjacent associations both with Afghanistan and Iran and coastal parts of the province have been remained the parts of Masqat \& Oman (Arab States) till late 196os. Balochistan has been given the status of province after the dissolution of annulment of one-unit in 1971 by Government of Pakistan. Since then, it has been working as a separate province of Pakistan with very low representation status at national levels at all the political and economic spheres of power and authority based on its low population, backwardness, and underdevelopment. Balochistan has not been one of the active parts of mainstream politics and economy at national level. That is why it has been remained the least developed region of the country (GOB, 2017; Jamali, 2007; Spooner, 2013).

Balochistan has been one of the least developed provinces of Pakistan. For its development strategies, the overview of the provincial geo-economic and socio-economic aspects are needed to put forth for governments, politics, comprehensive strategy development and public policies devising mechanism to take into notice the existing geo and socio-economic issues of the province (Ahmed, 2019).

\section{Research Methodology}

It is a review study to show some of the geo-economic and geo-social perspectives of Balochistan. The methodological approach of descriptive studies is used to compile the relevant set of text and literature for fulfilling the objectives of this study. The text set include available research studies, provincial reports, the official document of the "Rules of Business 2012" of government of Balochistan, studies and reports conducted and prepared by national and international organizations. The reviewed literature is then divided for composing thematic set of analyses in the context of government of Balochistan, physical geography, local and ethnicity, education, youth development, economic issues and opportunities and backwardness of the province (Sweetland, 996; Koh and Owen, 2000; Ahmed, 2019).

\section{Government of Balochistan}

Government of Balochistan Rules of Business (2012) defines Balochistan as one of the integrally federating units, constitutionally, of the Islamic Republic of Pakistan. Its constitutional head is Governor by title and constitutionally represents the Government of Pakistan at provincial level. The legislation is headed by Chief Minister (CM) of the province with its members of the provincial assembly. The executive body of the province in shape of cabinet (elected provincial assembly members) is working under the constitutionally provided responsibility of CM for the province. Several government departments have been established and made functional by the authority of the rules vested in the province Balochistan for carrying public sector official obligations to the people of Balochistan. Eighteenth amendments to the Constitution of Pakistan extended 
provincial autonomy to prepare, build capacity building, establish, exercise, implement, and get responsibility for the devolution of power in sectors like education, curriculum development, local and internal security, revenue generation and devising sources for revenue generation, local electoral system, labor and manpower development among many other areas of the power devolution for provincial autonomy (S\&GAD, 2012).

\section{Physical Geography}

In 1971, Balochistan in its present geographic shape was made a separate province by merging Pashtun-dominant Chief Commissioner's province and former states of Kalat, Mokran, and Bela. Gwadar became the part of Balochistan geographically in 1958 once it has been taken from one of the Arab states. The territory of Balochistan encompasses almost all the geographic states of mountains, plateaus, plain, and coastal areas in it-self. It constitutes around 43\% geography of Pakistan. It has coastal areas of about 700 to 800 kilometers spread along the Arabian sea. Balochistan may be divided into four zones of North-west high lands in upper Balochistan, Central uplands, Central plains, Coastal areas, and deserts with accumulation of all the fauna and flora of heights, ruggedness, and water distinctions over the surface of resourceful and lands of mines, minerals, and natural resources on its physical geography (Survey Pakistan, 2016).

\section{People and Ethnicity}

Pashtun, Baloch, are Brahvi are aboriginal ethnic groups of Balochistan. A very small portion of Hazaras, Punjabi, Sindhi, Hindus, Christians, and people from other ethnic groups and religious sects are also living in Balochistan. Balochistan is tri-dimensional ethnic province of Pakistan. Pashtun areas are populous and congested as compared to Baloch and Brahvi ethnic groups living in their own areas of aborigines. According to the 2017 Population Census, the largest ethnic groups in Balochistan are Balochs-cum-Brahvis (Baloch) that accounts for 55 percent of the population. The Census mixes Balochs and Brahvis into one group without their distinctions into two separate ethnic groups. The second largest ethnic group is Pashton that is around 30 percent of the population. Other small ethnic groups are settled and living mostly in Quetta, Sibi, and Bela districts of the province for business, commerce, services, and educational benefits only. Living and migration to the remote and rural areas of Balochistan for these minor groups are not beneficial due to the backwardness of rural areas in case of commerce, business, education, and standards of living (Population Census, 2017) (Ahmed \& Baloch, 2015; Population Census, 1998).

\section{Education}

Education is one of the most recognized factors for the development of a society, economy, or a country. Education in Balochistan is also not so advanced as compared to the other provinces of Pakistan. Literacy rate for both male and female are reported less in comparison with other provinces of Pakistan. Federal level statistics show that around $44 \%$ of the total population is literate in Balochistan; whereas, the situation in rural areas is more alarming where only $26 \%$ of population receive formal education and dropout ratio for girls is more than $70 \%$ before they get to ten years of formal schooling throughout the province (PSLM, 2013-14).

It has been mentioned in the literature that standards of living cannot be improved without enhancing education levels of the mass population of the province of Balochistan. They quoted several studies to relate illiteracy and poverty for the case of different developing economies of the world. They identified the factors of widespread poverty, poor educational standards, and complex structure of bribery, government jobs biasedness in favor of rich, and corruption in public sector 
domains responsible for widespread illiteracy and low levels of education for the people of Balochistan (A. Ahmed et al., 2018; M. Ahmed \& Baloch, 2015).

The levels of general education and skill development in the province have been lower than national level averages for technical and general education. Literacy rates both for male and female, skilled labor force, average productivity of labor, skill development, and employment opportunities for the provincial labor force have posed serious issues for properly investigating the skill development and their labor market outcomes in case of Balochistan.

\section{Provincial Youth}

Person of below 30 years of age constitutes $72 \%$ of the population in Balochistan (Population Census, 1998). Demographic forecasting about Balochistan shows that next cohort of young people in the population surpasses all the provinces of Pakistan (ESP-2012/13). Youth are faced with low literacy rate both at general education and skill formation levels in the province. There is a large disparity and huge gap between the provision of general education and TVET between male and female segments of youth in Balochistan. Rural urban disparity in provisioning of TVET and general education is also present. Employment opportunities are not matched with the skill/trade levels and local market requirements inside the rural and urban centers of economic activities (CHTED, 2017).

The official document of "Balochistan Youth Policy 2015" has categorized three potential challenges in fields of economy, society, and politics faced by youth in the province of Balochistan. Mapping issues from survey-based research and in-depth interviews across selected 30 districts of Balochistan, major issues in economic and social empowerment and political/civic engagement were found with sub-issues related to rural-urban, age groups, and male-female distribution for youth of Balochistan. The results of this study highlighted that youth of age-groups 20-24 and 24-29 have highest on unemployment. Female employability is also lower than male unemployment both in rural and urban settings. Civic, political, and social participation, representation, and mobility of females is also lower than male segment of the youth in the province. For economic empowerment and employability, quality general education, and market based TVET is recommended through the establishment of strong and dynamic institutional TVET set up in the province. District level skill-set with a balanced combination of both the general education with TVET and soft skills with hard skills are recommended for reducing unemployment in youth in general and particularly female youth to combat poverty and misery for the overall development of this backward province Balochistan (BYP, 2015).

Human development indicators are low in Balochistan as compared to other provinces of Pakistan. Low human capital in the province is due to low educational level, mass poverty, proportionally more rural inhibition of the province population, and low skills levels. Employment and livelihood opportunities are expected to be materialized by mega projects, 12 CPEC projects, emerging public and private sector employment opportunities, for the provincial youth through the acquisition of quality general technical and vocational skills, entrepreneurial skill, and economic activism in the province (Aliya H. Khan \& Aziz Ahmed, 2018).

\section{Economic Snapshot of the Province}

Balochistan has been the growing province of delicious fresh and dry fruit, vegetables, and a hub of mining and quarrying of mineral production over the years for both national and international markets Economic Survey of Pakistan (2016-17). Vast grazing areas, gigantic 
mountainous latitudinal zones give immense favor to breeding of cattle, sheep, and goats to produce meat and milk related many products. Coastal sea views give anchor to seaports and aquatic voyages over the years for aquatic trade and commerce with huge production of aquatic livestock to the country and neighboring states around Pakistan.

Economic Survey of Pakistan (2016-17) depicts Balochistan as shares of Pakistan along the three dimensions of geographic area as $44 \%$ of Pakistan's geography with contribution of $5 \%$ of Pakistan's population and around $4 \%$ of Pakistan's macro-economic volume in its survey reports.

Gazdar, Budhani, Mallah, and Khan (2007) and M. Ahmed and Baloch (2015) have mentioned that Balochistan is least developed in terms of human resources development, physical infrastructure, economic autonomy, and overall productivity in agriculture and industrial sectors as compared to other provinces of Pakistan. Per capita GDP in Balochistan is far lower than other provinces of Pakistan. For instance, from 1999 to 2010, the per capita GDP in Balochistan has shown a marginal increment from PKR27104 to PKR28503 (1399 PKR only!), whereas during the same period Punjab's per capita GDP increased from PKR 25420 to PKR 31664 (6244 PKR), indicating a $446 \%$ increment in case of Punjab for the same period of analysis.

Mohammed and Farooq (2002) recognized that the province has huge potentials of economic growth that may come through mineral resources, transit routes, and coastal development after the development of agriculture and industry while discussing the role of public sector. But, the fact is evidenced by M. Ahmed and Baloch (2015) reports that exploitation and depletion of minerals and natural resources discovered in Balochistan are same as the case for Sui gas exploitation which was discovered in 1952 in the province and supplied to industrial zones metropolitan areas of other provinces except Balochistan. Similarly, the study of M. Ahmed and Baloch (2015), while referring to the study of Grae (2006), mentions the example of resource exploitation of Balochistan by multinational firms of Sindak Copper project and Rek - e - Dik gold-copper projects respectively in Chagi District in 2002 in collaboration with Pakistani federal authorities in such a way that [“...the federal government entered into an agreement with a Chinese company to handover the Sandak Project. Under the agreement the Chinese company would fetch $80 \%$ of total profits back home, pay $18 \%$ to the federal government of Pakistan and disburse only $2 \%$ to Balochistan government as royalty charges. Rek-e-Dik gold-copper is the second major project in Balochistan that was given to Antofagasta of Chile and Barrick Gold of Canada. This project was aimed to exploit an estimate of 20 million ounces of gold and two billion tons of copper from Balochistan...”].

Agriculture, fisheries, and livestock dominate in rural areas of the province. Rural areas constitute more than $85 \%$ of the geographic area and employ around $65 \%$ of the labor force of the province. Apple, apricot, grapes, pomegranate, and other varieties of fruit of cold-cum-arid areas have been growing on upper and some central parts of Balochistan. Mangoes, dates, and oranges are being cultivated for mass productions in plains and hot areas of the province. Vegetables of around 20 varieties have been produced in the province and have been supplied to the other provinces as well for earnings. Balochistan contributes for 55 to $60 \%$ of cold season fresh fruit and 35 to $40 \%$ of vegetable varieties to the agriculture goods markets throughout Pakistan. Balochistan is highest growing province in terms of dry fruit production in Pakistan. Livestock and fisheries are producing both at mixed and commercial levels not only for the provincial need but also the major portion of the production are supplied to the markets of other provinces in Pakistan (GOB, 2017). 
The province is replete with natural resources of gas, oil, coal, copper and gold, marble, iron ore, chromite, gypsum, and other minerals. It has been reported the most resourceful province of Pakistan in terms of natural resources. It has minerals of natural gas, oil, coal, chromite, limestone, gold, copper, and other valuable natural resources. Gas and coal minerals have been widely and generously supplied and utilized by industry, energy sector, and domestically throughout Pakistan since 1952. Gas has been generating around PKR three billion to the economy of Pakistan. Districts of Chaghi and Noshki are replete with gold and copper minerals. "Saindak Copper Gold Project" in Chagai is working to exploit both the copper and gold resources and ironically contribute just $2 \%$ royalty to the Balchistan government. "Rekodik" is another copper and gold project that has been contributing 25\% share to Balochistan with the aim of tapping approximately two billion tons of copper and 20 million ounces of gold reserves with the expectation of revenue of Rs.200o million in royalties and share. Coal reserves are estimated around 260 million tons of sub-bituminous coal reserves present in Shahrag, Harnai, Bolan, Quetta, Sibi and Loralai districts of the province with the annual production of around 2 million tones to the energy, industrial, and domestic sectors of Pakistan. Marble and onyx export have been increased to US\$ 40 million in recent years from Balochistan. Chromite has been exported to China since early 1990s from the hills kakar regions of Muslimbagh and Qila Saifullah (M. Ahmed \& Baloch, 2015).

Kakar regions, Pishin, Qila Abdullah, Quetta, Kadkocha, Kalat, Naseerabad, and Jafarabad districts are having fertile soil fruit, vegetable, and food crops. Gwadar, Lasbela, Pasni, and other coastal areas are good sources for aquatic minerals and sea products like fisheries. Harnai, Loralai, and other upper areas of Balochistan are good sources for coal production to the industry inside the country. Muslimbagh is world renowned producing area of chromite quarrying for the last quarter of a century. Qila Saifullah, Loralai, Sibi, and Zhob areas are replete with non-staples, high valued coal, and other minerals. Due to lack of high technology, these minerals are limited to only mining and/or quarrying but not for more value addition and by products in the province. It is due to low technology availability to the common people of Balochistan, non-representation at national levels, and low level of investments in value addition to such minerals and resources. Sui has been recognized as the first ever producing areas of natural gas production to ignite and propel the engine of most of the industrial producing units as input for energy and domestic stoves out of the province but not in the province. The gas royalty has still been not settled formula-wise with the federal government in this regard and the case is still under settlement between the federation of Pakistan and its federating units including Balochistan province. Gwadar deep seaport is another mega project to benefit common people of Balochistan particularly and economy of Pakistan, in general. Yet it should bring its economic benefits once it gets momentum and becomes functional on commercial bases. It has been recently given under the Chinese authorities for functioning and commercial start up. Mines and minerals in the above-mentioned resources have strong likelihood for the development of the province on socio-economic and political fronts in Pakistan (GoB, 2017).

BYP (2015) mentions different economic corridors that may be used as channels for economic connectivity and development in the province. The proposed economic corridors are six in number in this vastly region of Pakistan. Farm to market roads and other channels for accessibility are not so advanced as compared to other provinces of Pakistan. Interconnectivity of roads is lowest in extent and ratios as the statistics from National Highway Authority suggest. The corridor from Karachi to Quetta is the most functional road type of mini corridor on the part of this province. Next to this is $600 \mathrm{~km}$ Coastal Highway that connects Gwadar port with Port Bin Qasim and coastal areas of Karachi. Gwadar-Mastung corridor links the districts from Gwadar to Kharan via single road by 
National Highway Authority. Port Mineral corridor interlinks all the districts from the district of Chagai to Gwadar. In the above-mentioned routes, one could glaringly see the importance of Gwadar with Quetta and Karachi. Other districts are interlinked for economic connectivity to the prospective port of Gwadar and capital cities of the provinces of Balochistan and Sindh.

The Western corridor links Quetta with districts of Pishin, Qila Saifullah, Loralai, Zhob, Sherani, and D. I. Khan to play its part in proposed China Pakistan Economic Corridor (CPEC). Gwadar would be made connected as an integral part of CPEC and road is being built to connect Gwadar with Quetta. The national level discussion on the proposals of Western, Central, and Eastern CPEC routes will determine economic future and economic security for the Western inhabitants of Balochistan. The federal government policy options on Western CPEC route once again seem to keep the people of upland Balochistan at arm's length from the benefits of CPEC prospective paybacks and may make the people become more vulnerable on economic fronts. The federal government has no political will to integrate the people of upper Balochistan in complex beneficial projections that CPEC and its allied macroeconomic activity will bring in near future.

There are 12 CPEC projects designed for the province for its socio-economic development in the overall multi-billion CPEC project between Pakistan and China. These 12 projects include Gwadar development authority, deep seaport, energy sector, water and fisheries, mega project for Quetta city, industrial development, human resource development, governance, and provision of TVET education for skill development in the province. One Road One Belt Conference (2017) in China has recognized the prominence of Gwadar deep-sea port and abundance of natural resources of Balochistan as very important and necessary for the successful completion of proposed USD 56 billion worth of CPEC project and their prospective economic benefits to Pakistan and Balochistan alike. Gwadar smart city project, development and functioning of deep sea port for international trade and commerce, energy and power productions, exploration and value-addition of mines and minerals, leasing of huge land resources for Chinese and foreign investors to commercially start the cultivation of agriculture products, investment opportunities in livestock and fisheries for export purposes, human resource development, and exploiting other economic opportunities under the auspices of overall CPEC project in Balochistan.

\section{Backwardness of the Province}

Backwardness of the province of Balochistan has been traced to Pakistan's resource distribution formula and strategies for financing projects with the help of national pool of revenues and financial resources that have been in favor of dominant provinces other than Balochistan. National Financial Commission (NFC) award formula has never been in favor of the province of Balochistan due to reasons of low population base, misrepresentation at national levels, backwardness, political weakness, and low base for revenue generation. It has been mentioned for comparison that the province of Punjab has remained the favorable destination for projects selection due to its majority seats in the National Assembly during democratic regimes and in getting and attracting excessively a bigger part of public resources in dictatorial regimes since majority of military and civil bureaucracy personnel belongs to the same province (Ahmed and Baloch, 2015; Aasim, 2007; Zaidi, 2005).

Bengali, Pasha, and Ghaus (2005) in the book of Griffiths (2005) clearly state that Balochistan's share of Pakistan's GDP has been dropped from 4.9 to less than 3\% of Pakistan's GDP from 1974/75 to 1999/200o, respectively, due to many socio-political, federal-provincial, dominance 
and weak bargaining powers, unjustifiable federal resource distribution formula, inactive economic and low population base, political misrepresentation, and other attributes responsible for the backwardness of Balochistan.

Thus, the province of Balochistan is the least developed province of Pakistan. Standards of living are not so promising as compared with rest of the country. Education level is the lowest both at rural/urban and male/female levels in Pakistan. It is a resourceful province yet the least developed on economic fronts in Pakistan. Political representation is the lowest in strength and numbers at national assembly level than all the remaining provinces of Pakistan. Indicators of industry, agriculture, services, capital formation, tax collection, and to mention a few are proverbially at lower levels than the same estimated indicators of other provinces of Pakistan (Balochistan Education Sector Plan, 2013-2018). Health facilities per person are not reached to the levels of overall facilities available to average Pakistanis. Physical infrastructure in shapes of roads, bridges, airports, and seaports are yet to be constructed to connect this backward province to the proposed CPEC designed by Pakistan and China as a game change and mega project for economic change and prosperity to this region. Major portion of the province are representing high in deprivation indicators for society, economy, education, and political rights to show the backwardness of the province. The following Table shows deprivation levels in three categories of low, medium, and high in one the studies of (Jamal, 2011).

Table. A.2.1. Balochistan: District-wise Ranking in Indices of Multiple Deprivations

\begin{tabular}{|l|l|l|l|l|l|}
\hline \multicolumn{2}{|l|}{ Deprivation Level } & \multicolumn{2}{l|}{ Deprivation Level } & \multicolumn{2}{l|}{ Deprivation Level } \\
\hline LOW & \multicolumn{2}{l|}{ MEDIUM } & \multicolumn{2}{l|}{ HIGH } \\
\hline 1 & Quetta & 11 & Bolan/Kachhi & 21 & Kech/Turbat \\
\hline 2 & Pishin & 12 & Gwadar & 22 & Nushki \\
\hline 3 & Harnai & 13 & Khuzdar & 23 & Killah Saifullah \\
\hline 4 & Ziarat & 14 & Awaran & 24 & Lasbela \\
\hline 5 & Killah Abdullah & 15 & Kharan & 25 & Musakhel \\
\hline 6 & Sibbi & 16 & Nasirabad & 26 & Chagai \\
\hline 7 & Mastung & 17 & Panjgur & 27 & Barkhan \\
\hline 8 & Jafarabad & 18 & Sherani & 28 & Loralai \\
\hline 9 & Kalat & 19 & Zhob & 29 & Kohlu \\
\hline 10 & Jhal Magsi & 20 & Washuk & 30 & Dera Bugti \\
\hline
\end{tabular}

Source: Jamal, Haroon. "Districts' Indices of Multiple Deprivations for Pakistan," Social Policy and Development Centre: Karachi: 2012.

The economic challenges of mass poverty, include unemployment, low skill development, lack of labor market information, seldom access to economic opportunities for the youth, conventional mode for economic and business relation development, gender biasedness, tribalism for low economic development, and dearth of investment in human capital formation are reported (BYP, 2015). Conventional and mostly subsistence way of farming, agriculture, livestock and fisheries have accommodated around 50\% of the employed people in Balochistan. Employment in the abovementioned areas of economic activities are seasonal and discontinued throughout the year due to seasonal cultivation and farming nature, lack of irrigation system, arid zone effects, and conventional ways of water irrigation like, the presence of "karez" system (i.e. under-ground water tunnel system for drinking and irrigation purposes) in up hills areas of the province. Employment in wholesale and 
retail trade is around $15 \%$, the second biggest sector, in the province. Skill development ratio is low as compared to other provinces of Pakistan (GOB, 2017).

Civic engagement is also reported to be very low for the youth of Balochistan. Many reasons like, feudalism, tribalism, low education and exposure, rural set-up, gender bias, low mobility, low connectivity, low political and civic engagement in public affairs, constraint social and political mobility, and other civic and political sub-issues hinder the developments of youths' career and active participations in public affairs both at provincial and national levels.

Social empowerment constraint is another major problem faced by common people in Balochistan. People are divided into sub casts and sub-tribal branches, persistence of enmities by sub-casts and tribes, social immobility on the part of youth and female segment, illiteracy, poverty and economic dependence on conventional mode of economic activities, political problems of misrepresentation, taboos and myths about the development social and tribal interactions, unnecessary influence of the tribal chiefs and households' head, feudalism, lack of male and female interaction, political illiteracy, and inefficient public sector involvement for social empowerment are problems that contribute to backwardness of the province in Balochistan.

Recent layer of terrorism has been affecting negatively many sectors of economy, politics, and society for the last ten years in the province. Security issues, kidnapping, insurgency, militancy, extremism, human rights violation, less efficiency of security forces to combat terrorism, and local/tribal enmity are some of the attributes to further enhance backwardness and nondevelopment in the province (Economic Survey of Pakistan, 2016-17; Home Department, 2018).

Gender misrepresentation and women at household level, business, job priority, education, society affairs, and politics are not given priority due to tribalism, conventionality, and other socioeconomic constraints in the province. Gender disparity in favor of male segment of the population in economy, politics, society, culture, sports, and other sectors/fields is one of the glaring examples of backwardness and conventionality prevalent in this backward province of Pakistan (Women Development Department, 2016).

BYP (2015) has identified that unemployment mostly for youth segment of the population, civic problems, mass poverty, weak infrastructure, political and tribal issues, low levels of education and skill development are major issues that contribute to the low levels of living and economic backwardness of the resource-rich but least developed province of Pakistan.

The BYP (2015) recognizes that skill development and vocational training focusing and in line with the regional clustering and economic corridors could yield prospective labor market outcomes and fortunes for the youth in the province. BYP recommends for policy to carry out skills mapping studies to ascertain district-level skill sets in each economic corridor and emphasis upon encouraging exploratory studies and skill mapping and labor market analysis in Balochistan.

One of the objectives of this study is to fulfill the above-mentioned need that may contribute to the empirics of and policy parameters for skill development, labor market information, TVET impact on employment and earnings, schooling-earnings nexus for TVET, and other attributes to the literature concerned in labor economics, economics for education, and theories of human capital formation in the perspective of the province of Balochistan. 


\section{Conclusion}

The review of the literature shows the evidence of geo and socio-economic backwardness for the province and its people in case of Balochistan. It has long and rich history composed of culturally civilized people and tribes, but they are facing with miseries of socio-economic development. The province is full of natural minerals and resources and having vast coastal areas, yet the socioeconomic indices show the provincial districts are the most deprived districts in terms of development. There is presence of growing youth population, but they are lacking education, human capital formation and skills development to earn decent livelihood. The economic problems of not having industrial set-ups, low skilled population, lack of basic incomes, mass unemployment, nonfunctional of coastal areas for economic activities, lack of special economic and free trade zones, incapability of provincial departments and its incompetent and mentally sick and corrupt bureaucracy, hectic and red-tapes attitudes in government departmental affairs, low political awareness by the tribal and nationalist political leaders, exploitative nature of tribalism, conventionality in day to day affairs and low investment opportunities are factors for the backwardness of the province. The policy options include ownership of natural resource development to local Balochs and Pashtuns, human capital formation of its labor force, coastal area development, development of Gwadar sea-port, enhancing capacity building of the provincial government departments, rule of law, investment for socio-economic development and mainstreaming the local population in macro decision making for the development of the least developed province of Balochistan.

\section{References}

Abul Rauf (2017). [Personal Communication on 23/05/2017], Regional Director, NAVTTC, Jinnah Town, Quetta.

Ahmed, A. (2018a). Impacts of Vocational Training for Socio-economic Development of Afghan Refugees in Labor Markets of Host Societies in Baluchistan. Journal of International Migration and Integration. doi:10.1007/s12134-018-0627-4

Ahmed, A. (2018b). Impacts of Vocational Training for Socio-economic Development of Afghan Refugees in Labor Markets of Host Societies in Baluchistan. Journal of International Migration and Integration, 1-18.

Ahmed, A., \& Khan, A. (2018). SWOT analysis of institutional framework for engineering diplomas in technical and vocational education and training system in Pakistan. Paper presented at the IOP Conference Series: Materials Science and Engineering.

Ahmed, A., Khan, A. H., Shehnaz, L., Muhammad, W., \& Ullah, S. W. (2018). Human resource development through technical and vocational education and trainings (TVET) system in Baluchistan: A critical SWOT analysis.

Ahmed, M., \& Baloch, A. (2015). Political Economy of Balochistan, Pakistan: A Critical Review. European Scientific Journal, 11(14).

Asian Development Bank. (2002). Technical Assistance to Pakistan for Restructuring of the Technical Education and Vocational Training System Project (Balochistan) Retrieved from Manila, Philippines:

Balochistan Education Sector Plan. (2013-2018). Balochistan Education Sector Plan, Policy Planning and Implementation Unit (PPIU), Education Department, Government of Balochistan. Quetta.

Balochistan Youth Policy. (2015). Balochistan Youth Policy. Government of Balochistan.

Balochistan, G. o. (2015). Balochistan Youth Policy 2015. Environment, Sports \& Youth Affairs Department. Civil Secretariat. Quetta.

Bank, A. D. (2009). Education and skills: Strategies for accelerated development in Asia and the 
Pacific. Retrieved from Manila, Philippines:

BRSP. (2017). Livelyhood Program for Skills. Balochistan Rural Support Program, Quetta.

B-TEVTA Act no. II of 2011, (2011), Balochistan Technical Education and Vocational Training Authority, Government of Balochistan, Quetta.

B-TEVTA. (2018). Balochistan Technical Education and Vocational Training Authority-Act (2011), Rules of Business, Government of Balchistan, Quetta.

BYP. (2015). Balochistan Youth Policy. Ministry of Culture and Youth affairs, Government of Balochistan, Quetta.

DPJA. (2017). Skills Industry Mach Jail. Interior Ministry, Government of Balochistan, Quetta.

Economic Survey of Pakistan. (2016-17). Economic Survey of Pakistan. Islamabad Retrieved from http://www.finance.gov.pk/survey/chapters_17/Pakistan_ES_2016_17_pdf.pdf.

German Federal Ministry for Economic Cooperation and Development. (2017-2019). Supporting technical and vocational education and training (TVET) reform in Pakistan.

GOB. (2017). Press Release, Government of Balochistan. Quetta.

GOP-PBS. (1998). Population Census 1998, Pakistan Bureau of Statistics, Statistics Division, Islamabad.

Government of Pakistan. (2015). National Skill Policy. Skills for Growth \& Development: A Technical and Vocational Education and Training (TVET) Policy for Pakistan. Ministry of Federal Education and Professional Training, Islamabad.

Home Department. (2018). Security Measures by Government, Quetta.

I\&CD. (2017). Rules of Business (2012), Government of Balochistan, Quetta.

Jamal, H. (2011). Districts' Indices of Multiple Deprivations for Pakistan, 2011. Social Policy and Development Center (SPDC), Research Report, 82.

Jamali, H. (2007). Anthropologists Should Shed Light on the Violence in Balochistan Province, Pakistan. Anthropology News, 48(5), 37-38.

Khan, A. H., \& Ahmed, A. (2018). Identification of Relevant Technical \& Vocational Skills for Job Growth \& Human Resource Development in the Context of CPEC Projects for Balochistan (Research Paper ed., Vol. 400ooo, pp. 12). Baluchistan: CoE-CPEC, PIDE, Islamabad, Pakistan.

Khan, F. S., \& Toor, I. A. (2003). Changes in Returns to Education in Pakistan: 1990-2002.

Khan, M., Akhtar, S., Mehmood, H. Z., \& Muhmood, K. (2013). Analysing skills, education and wages in Faisalabad: Implications for labour market. Procedia Economics and Finance, 5, 423-432.

Khan, S. R., Irfan, M., \& Cohen, S. I. (1985). Rates of Returns to Education and the Determinants of Earnings in Pakistan [with Comments]. The Pakistan Development Review, 24(3/4), 671-683.

Koh E.T., Owen W.L. (2000) Descriptive Research and Qualitative Research. In: Introduction to Nutrition and Health Research. Springer, Boston, MA. https://doi.org/10.1007/978-1-46151401-5_12

Kosfeld, R., \& Dreger, C. (2006). Thresholds for employment and unemployment: A spatial analysis of German regional labour markets, 1992-2000. Papers in Regional Science, 85(4), 523-542.

KP-TEVTA. (2018). The Khyber Pakhtunkhwa Technical Education and Vocational Training Authority. Retrieved from http://kptevta.gov.pk/kptevta/

Krapp, S. (1999). The educational and vocational training system in Egypt: Development, structure, problems. International journal of sociology, 29(1), 66-96.

L\&MPD. (2017). Rules of Business (2012). Quetta.

Labor Force Survey. (2015-16). Labour Force Survey 2015-16. Retrieved from Pakistan Bureau of Statistics, Statistics House, 21-Mauve Area, G-9/1, Islamabad, Pakistan: http://www.pbs.gov.pk/content/labour-force-survey-2015-16-annual-report

Mercy Corps. (2016). Training Provision to Afghan Refugees \& Host Communities. Quetta Chapter. 
Mohammed, J., \& Farooq, S. U. (2002). The role of public sector in the economic development of Balochistan. The Dialogue, 3(4), 472-494.

NAVTTC. (2016a). National Skill Information System. Sector F-5/1, Islamabad: NAVTTC.

NAVTTC. (2016b). Skills Trend in Textile Industry Pakistan. A case study of Faisalabad district. Retrieved from F 5-1 Islamabad:

NAVTTC. (2017). National Skill Information System (NSIS) Section. Islamabad Retrieved from http://navttc.org/?page_id=1173\#tab-id-1 to 6

NAVTTC. (2018). National Vocational \& Technical Training Commission (NAVTTC), Pakistan. Government of Pakistan. Retrieved from http://www.navttc.org/

Office, I. L. (1985). General report: International Labour Office.

Planning Commission. (2015). Pakistan Vision-2025. Islamabad.

Planning Commission. (2016). CPEC Related Press Release. Federal Ministry of Planning \& Development, Islamabad.

Population Census. (2017). Population Census 2017, Pakistan Bureau of Statistics, Government of Pakistan. Islamabad.

PSLM. (2013-14). Pakistan Social and Living Standards Measurement, Pakistan Bureau of Statistics, Government of Pakistan.

P-TEVTA. (2018). Punjab Technical Education \& Vocational Training Authority. Retrieved from http://www.tevta.gop.pk/

S\&GAD. (2012). Rules of Business. Quetta Retrieved from http://balochistan.gov.pk/Downloads/SERVICE\%20Rules\%20S\&GAD\%202013/Balochistan \%20Government\%2oRules\%20of\%2oBusiness\%202012/Balochistan\%2oGovernment\%2oR ules\%20of\%2oBusiness\%202012.pdf.

Social Welfare Department. (2017). Social Welfare Department. Rules of Business, 2012. Quetta.

Spooner, B. (2013). The Baloch in Islamic Civilization, Western Ethnography, and World History. The Journal of the Middle East and Africa, 4(2), 135-151.

S-TEVTA. (2018). Sindh Technical Education \& Vocational Training Authority. Retrieved from http://www.stevta.gos.pk/

Sweetland, S. R. (1996). Human capital theory: Foundations of a field of inquiry. Review of educational research, 66(3), 341-359.

Women Development Department. (2016). Gender Policy Action Plan 2016-2020, Government of Balochistan, Quetta.

Zaidi, S. A. (2005). Issues in Pakistan's economy. OUP Catalogue. 